\title{
Aspekty pielęgniarskie pacjenta z zespołem kacheksja - anoreksja w opiece paliatywnej - studium przypadku w oparciu o Międzynarodową Klasyfikację Praktyki Pielęgniarskiej ICNP ${ }^{\circledR}$
}

Nursing aspects of care in patient with cachexia-anorexia in palliative care - case study based on ICNP $^{\circledR}$

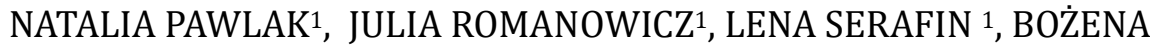
CZARKOWSKA-PĄCZEK ${ }^{2}$

${ }^{1}$ Studenckie Koło Naukowe Pielęgniarstwa Klinicznego, Wydział Nauki o Zdrowi, Warszawski Uniwersytet Medyczny

2Zakład Pielęgniarstwa Kliniczego, Wydział Nauki o Zdrowiu, Warszawski Uniwersytet Medyczny

DOI: http://dx.doi.org/10.21784//wP.2019.011

ISSN: 2451-1846

\section{Streszczenie:}

Wstęp. Opieka paliatywna ma na celu poprawę jakości życia uwzględniając wszystkie jego aspekty: psychiczny, fizyczny i duchowy, w momencie, kiedy odstępuje się od leczenia przyczynowego, a stosuje leczenie objawowe. Zespól kacheksja-anoreksja występuje u około 75\% pacjentów z chorobą nowotworową w stopniu zaawansowanym i stanowi zespół objawów, które mają istotny wpływ zarówno na kondycję fizyczną pacjenta, jak i jego funkcjonowanie psychospołeczne. 
Cel pracy. Celem pracy jest przedstawienie problemów pielęgnacyjnych występujących u pacjentki $\mathrm{z}$ zespołem kacheksja-anoreksja leczonej paliatywnie.

Prezentacja przypadku. Pacjentka hospitalizowana w oddziale opieki paliatywnej w celu objawowego leczenia zdiagnozowanego wieloogniskowego nisko zróżnicowanego gruczolakoraka jajnika w IV stopniu zaawansowania klinicznego oraz kacheksji. Wśród licznych problemów pielęgnacyjnych jako najważniejsze wskazano: ból, problemy $\mathrm{w}$ komunikowaniu się z otoczeniem, ryzyko wystąpienia infekcji z powodu obecności portu donaczyniowego oraz odleżyny. Ponadto pacjentka prezentuje deficyt $w$ zakresie samoopieki oraz samopielęgnacji. Obawia się o dalsze losy w procesie terapeutycznym.

Dyskusja. Wdrożenie działań zapobiegających rozwojowi problemów pielęgnacyjnych zdiagnozowanych u pacjentki stanowi wyzwanie dla zespołu terapeutycznego oraz rodziny. Zaproponowany plan opieki pielęgniarskiej miał przede wszystkim, zgodnie w priorytetem realizowanej opieki, podnieść jakość życia chorej. Najbardziej uciążliwym objawem występującym u opisywanej chorej był ból. Dolegliwość ta jest jednym z najczęstszych objawów diagnozowanych u pacjentów wopiece paliatywnej. W praktyce pielęgniarskiej bardzo istotna jest wnikliwa obserwacja czynników determinujących ból oraz ocena jego charakteru i nasilenia.

Wnioski. Zastosowanie Międzynarodowej Klasyfikacji Praktyki Pielęgniarskiej ICNP ${ }^{\circledR}$ w planowaniu opieki pielęgniarskiej nad pacjentką z zespołem kacheksja - anoreksja umożliwiło monitorowanie oraz poprawę efektywności oraz jakości udzielanych świadczeń w procesie terapeutycznym.

Słowa kluczowe: opieka paliatywna, zespół kacheksja - anoreksja, proces pielęgnowania, ICNP ${ }^{\circledR}$

Abstract:

Introduction. Palliative care seeks to improve the quality of life considering all its aspects: psychological, physical and spiritual, at the moment when causal treatment is being withdrawn in favour of symptomatic treatment. 
Cachexia-anorexia occurs in $75 \%$ of patients with advanced cancer and is characterized by symptoms which have a significant influence on physical fitness and mental strengths.

Aim of the study. The aim of the study is to present nursing problems in patient with cachexia-anorexia in palliative care.

Case study. Patient hospitalized in the terminal ward for symptomatic treatment of diagnosed multifocal low-differentiated ovarian adenocarcinoma in stage IV and cachexia. Among numerous nursing problems, as most important, they pointed: pain, problems in communicating with the environment, the risk of the appearance of infection because of the presence of the intravascular harbor and bedsores were identified as the main problems. Moreover, the patient has deficits in self-care. She also fears the therapeutic process.

Discussion. The implementation of the actions of preventing nursing problems is a challenge for the therapeutic team and families. The suggested plan of nuring care, in line with the care carried out, aimed to raise the patient's quality of life. One of the most troublesome symptoms identified was pain. Severe pain and suffering is one of the most frequent symptoms diagnosed in patients in palliative care. Thorough observation of determinants of pain is of significant importance in nursing care.

Conclusions. Applying The International Classification for Nursing Practice ICNP $®$ in the planning of nursing care for a patient with cachexia - anorexia enabled monitoring and improvement of the efficiency and quality of services provided in the therapeutic process.

Keywords: palliative care, cachexia syndrome - anorexia, nursing process, $\mathrm{ICNP}^{\circledR}$

\section{Wstęp}


Główne założenia opieki paliatywnej polegają na realizacji świadczeń, które mają na celu niesienie ulgi w cierpieniu, uśmierzanie bólu i innych objawów somatycznych, łagodzenie problemów psychosocjalnych, duchowych oraz wsparcie bliskich osoby chorej. Działania te stanowią interdyscyplinarne postępowanie mające na celu poprawę jakości życia chorych z postępującą, zagrażającą życiu chorobą. W Polsce opieką paliatywną obejmowani są głównie pacjenci $\mathrm{z}$ chorobami nowotworowymi, które coraz częściej, ze względu na swój charakter, określane są jako przewlekłe [1].

Zespół kacheksja-anoreksja charakteryzuje się brakiem apetytu oraz zmniejszeniem masy ciała kosztem masy mięśniowej oraz tkanki tłuszczowej. Występuje ono u 75\% chorych w zaawansowanym stadium choroby nowotworowej [2]. Kacheksja jest jednym z najczęstszych zespołów metabolicznych u pacjentów z zaawansowaną chorobą nowotworową i wiąże się zograniczeniem aktywności fizycznej, gorszymi wynikami leczenia, gorszą jakością życia oraz zwiększeniem ryzyka zgonu [3]. Zespół kacheksjaanoreksja jest złożonym zespołem, który często definiuje się zarówno w kontekście przyczyn pierwotnych, jak i wtórnych. Pierwotne przyczyny są związane ze zmianami metabolicznymi i neuroendokrynnymi bezpośrednio wynikającymi $\mathrm{z}$ choroby podstawowej oraz towarzyszącego stanu zapalnego. Wtórnymi przyczynami są natomiast inne czynniki występujące w przebiegu choroby podstawowej, takie jak ból, duszność, zmęczenie, infekcja itp., które również przyczyniają się do utraty masy ciała [4].

Leczenie zespołu kacheksja - anoreksja koncentruje się na poprawie stanu odżywienia chorego, a jego podstawą jest wprowadzenie zbilansowanej diety. Jeśli to konieczne, stosuje się doustne suplementy pokarmowe, leki pobudzające apetyt lub nawet leczenie żywieniowe (dojelitowe lub pozajelitowe) [5]. Kluczowym aspektem terapii jest wczesne rozpoznanie i interwencja. Skierowanie pacjentów zagrożonych wyniszczeniem do interdyscyplinarnej opieki 
paliatywnej powinno być pierwszym działaniem mającym na celu łagodzenie objawów oraz poprawę jakości życia [3].

Zespół kacheksja-anoreksja stanowi zespół objawów, które mają istotny wpływ zarówno na kondycję fizyczną pacjenta, jak i jego funkcjonowanie psychospołeczne. Łagodzenie objawów kacheksji pozwala na poprawę jakości życia chorego i jego najbliższych [6]. Postępowanie terapeutyczne powinno angażować wszystkich członków zespołu interdyscyplinarnego, w tym również pielęgniarki. Rozpoznawanie problemów pielęgnacyjnych oraz podejmowanie interwencji adekwatnych do objawów i potrzeb chorego, pozwalają minimalizować negatywne skutki choroby.

Dlatego celem pracy jest identyfikacja i prezentacja problemów pielęgnacyjnych występujących u pacjentki, z rozpoznaniem zespołu kacheksja - anoreksja w przebiegu choroby nowotworowej, będącej $\mathrm{w}$ trakcie leczenia paliatywnego. W planowaniu opieki pielęgniarskiej odwołano się zarówno do tradycyjnego modelu procesu pielęgnowania, jak również opracowano diagnozy oraz interwencje w oparciu o Międzynarodową Klasyfikację Praktyki Pielęgniarskiej ICNP®.

\section{Prezentacja przypadku}

Pacjentka, lat 66, hospitalizowana była w oddziale opiekipaliatywnej w celu objawowego leczenia zdiagnozowanego w lutym 2018 roku wieloogniskowego, niskozróżnicowanego gruczolakoraka jajnika w IV stopniu zaawansowania klinicznego oraz kacheksji. Z uwagi na stopień zaawansowania choroby odstapiono od leczenia przyczynowego. W badaniu podmiotowym stwierdzono, że pacjentka przebyła dwa zabiegi operacyjne: tyreoidektomię (2015r.) oraz wycięcie macicy z przydatkami (2017r.). Neguje wypadki i urazy w przeszłości.

W grudniu 2018 roku chora przebyła udar niedokrwienny mózgu (lewostronny), czego skutkamisąniedowład prawostronny, 
który w znacznym stopniu ograniczył zdolności motoryczne pacjentki oraz afazja.Ze względu na trudność w przyjmowaniu posiłków drogą doustną, chora jest żywiona pozajelitowo (port donaczyniowy). Sygnalizuje nasilające się od kilku dni nudności. Jest uzależniona od nikotyny.

Przy przyjęciu chorej do oddziału opieki paliatywnej przeprowadzono badanie przedmiotowe ogólne oraz zbadano pacjentkę pod kątem stanu psychicznego (orientacja autopsychiczna oraz orientacja allopsychiczna), przytomności (Skala Glasgow)oraz mowy.

Badanie fiykalne w dniu przyjecia wykazałodwie odleżyny III (wg skali Torrence'a) na pośladku prawym $(2,5 \mathrm{~cm} \times 3 \mathrm{~cm})$ oraz kości ogonowej $(2,5 \mathrm{~cm} \times 2 \mathrm{~cm})$.

$\mathrm{Z}$ wywiadu przeprowadzonego $\mathrm{z}$ rodziną chorej wiadomo, że pacjentka niechętnie zmienia pozycję ułożeniową. Zaobserwowano dysfunkcje budowy ciała oraz stanu odżywienia chorej. Wzrost $(1,67 \mathrm{~m})$ oraz waga $(52 \mathrm{~kg})$ pacjentki świadczą o znacznej niedowadze (BMI 16,1). Zdiagnozowano również wodobrzusze III stopnia.

Ponadto, stan chorej został oceniony wg następujących skal: Skala Douglas (10 pkt.),Skala Barthel (10 pkt), Skala VAS (7pkt.),Skala Glasgow (12 pkt.).

Pacjentka prezentuje deficyt $\mathrm{w}$ zakresie samoopieki i samopielęgnacji. Obawia się o dalsze losy w procesie terapeutycznym.

W tabeli 1. zaprezentowano szczegółowe informacje charakeryujące opisywaną pacjentkę oraz wynik badań: podmiotowego i przedmiotowego.

Tabela 1. Arkusz indywidualnego opisu przypadku opracowanie na podstawie Lesińska-Sawicka M (2009) [7].

DANE SOCJODEMOGRAFICZNE 


\begin{tabular}{|c|c|}
\hline Rok urodzenia: $1953 r$. & Płeć: kobieta \\
\hline Stan cywilny: mężatka & $\begin{array}{l}\text { Wykonywany zawód: } \\
\text { emeryturze) }\end{array}$ \\
\hline \multicolumn{2}{|c|}{ STAN OGÓLNY (podczas zbierania wywiadu) } \\
\hline \multicolumn{2}{|l|}{ Temperatura: $36,7^{\circ} \mathrm{C}$} \\
\hline \multicolumn{2}{|c|}{$\begin{array}{l}\text { Tętno: (liczba / napięcie / rytm) 95/min/dobrze napięte/dobrze } \\
\text { wyczuwalne }\end{array}$} \\
\hline \multicolumn{2}{|l|}{ Oddechy: $15 / \mathrm{min}$} \\
\hline \multicolumn{2}{|c|}{ Ciśnienie tętnicze: $123 / 92 \mathrm{mmHg}$} \\
\hline \multicolumn{2}{|l|}{ Masa ciała: $52 \mathrm{~kg}$} \\
\hline \multicolumn{2}{|l|}{ Wzrost: $167 \mathrm{~cm}$} \\
\hline \multicolumn{2}{|l|}{ WYWIAD RODZINNY } \\
\hline \multicolumn{2}{|c|}{ Członkowie rodziny: mąż (65 lat), córka (31 lat), syn (27 lat) } \\
\hline \multicolumn{2}{|c|}{ Ważne wydarzenia w rodzinie - ostatnie lata: nie podaje } \\
\hline \multicolumn{2}{|c|}{$\begin{array}{l}\text { Choroby występujące } \mathrm{w} \text { rodzinie: rak jelita grubego, nadciśnienie } \\
\text { tętnicze, choroba wieńcowa serca }\end{array}$} \\
\hline \multicolumn{2}{|c|}{ Hobby/zainteresowania: gotowanie, florystyka } \\
\hline \multicolumn{2}{|c|}{ Formy spędzania czasu wolnego: nie podaje } \\
\hline \multicolumn{2}{|c|}{ Nałogi w rodzinie: nikotynizm } \\
\hline \multicolumn{2}{|c|}{ Błędy żywieniowe (jakościowe i ilościowe): nie podaje } \\
\hline \multicolumn{2}{|c|}{ Ograniczenia/przeciążenia psychiczne/fizyczne: niedowład } \\
\hline \multicolumn{2}{|c|}{ Ograniczone kontakty/brak wsparcia społecznego: nie podaje } \\
\hline
\end{tabular}


Tabela 2. Badanie fizykalne - opracowanie na podstawie Lesińska-

Sawicka M (2009) [7].

\begin{tabular}{|c|c|c|c|c|}
\hline \multicolumn{5}{|c|}{ Stan biologiczny podopiecznego } \\
\hline \multicolumn{5}{|c|}{ UKŁAD ODDECHOWY } \\
\hline $\begin{array}{l}\text { liczba } \\
\text { oddechów }\end{array}$ & typ oddechu & kaszel & \multicolumn{2}{|l|}{ inne objawy } \\
\hline $15 / \min$ & prawidłowy & brak & \multicolumn{2}{|l|}{ brak } \\
\hline \multicolumn{5}{|c|}{ UKŁAD KRĄŻENIA } \\
\hline \multirow{2}{*}{$\begin{array}{l}\text { Cisnienie } \\
123 / 92 \mathrm{mmHg}\end{array}$} & tętno & sinica & obrzęki & duszność \\
\hline & 95/min. & brak & wodobrzusze & brak \\
\hline \multicolumn{5}{|c|}{ UKŁAD POKARMOWY } \\
\hline uzębienie & łaknienie & stolec & dieta & inne \\
\hline $\begin{array}{l}\text { bez protezy } \\
\text { zębowej }\end{array}$ & obniżone & $\begin{array}{l}\text { zmieniony } \\
\text { formą, } \\
\text { rozwodniony }\end{array}$ & $\begin{array}{l}\text { Dieta ze } \\
\text { szczególnym } \\
\text { uwzględnienie: } \\
\text { białka, płynów. }\end{array}$ & $\begin{array}{l}\text { karmienie } \\
\text { pozajelitowe }\end{array}$ \\
\hline \multicolumn{5}{|c|}{ UKŁAD MOCZOWY } \\
\hline $\begin{array}{l}\text { objętość } \\
\text { moczu }\end{array}$ & jakość & inne objawy & \multicolumn{2}{|c|}{ wyroby medyczne } \\
\hline $1600 \mathrm{ml}$ & $\begin{array}{l}\text { klarowny, } \\
\text { barwy } \\
\text { słomkowej } \\
\text { bez } \\
\text { domieszek } \\
\text { krwi }\end{array}$ & nie podaje & \multicolumn{2}{|c|}{ Cewnik Foleya } \\
\hline \multicolumn{5}{|c|}{ UKŁAD PŁCIOWY } \\
\hline \multicolumn{2}{|l|}{ cykl płciowy } & \multicolumn{3}{|c|}{ inne cechy* } \\
\hline \multicolumn{2}{|c|}{ adekwatny do wieku } & \multicolumn{3}{|l|}{ brak } \\
\hline \multicolumn{5}{|c|}{ UKŁAD NERWOWY } \\
\hline $\begin{array}{l}\text { świadomość } \\
\text { wg skali }\end{array}$ & $\begin{array}{l}\text { niedowłady/ } \\
\text { drżenia }\end{array}$ & mowa & \multicolumn{2}{|l|}{ inne objawy } \\
\hline
\end{tabular}




\begin{tabular}{|l|l|l|l|}
\hline Glasgow & & & \\
\hline $\begin{array}{l}12 \text { pkt chory } \\
\text { przytomny }\end{array}$ & $\begin{array}{l}\text { niedowład } \\
\text { prawostronny }\end{array}$ & afazja & brak \\
\hline
\end{tabular}

Źródło: wynik badań własnych

\section{Diagnoza i interwencja pielęgniarska}

Po przeprowadzeniu badania podmiotowego oraz przedmiotowego zdiagnozowano u chorej następujące problemy pielęgnacyjne: ból w obrębie jamy brzusznej, trudności w komunikowaniu się, ryzyko wystąpienia infekcji $\mathrm{z}$ powodu założonego portu donaczyniowego, ryzyko pogłębienia i zwiększenia odleżyny, wodobrzusze,deficyt samoopieki i samopielęgnacji w związku z niedowładem prawostronnym, nudności, obniżony nastrój spowodowany potrzebą hospitalizacji, lęk.

Poniżej zaprezentowano plan opieki pielęgniarskiej $\mathrm{w}$ odniesieniu do wybranych problemów pacjentki przedstawionej $\mathrm{w}$ opisie przypadku z wykorzystaniem ICNP@is (Tabela 3.). Opieka nad chorą była realizowana przez dwa tygodnie.

Opieka została zrealizowana w oparciu o modele:

1. Callisty Roy - mechanizm ten opiera się na adaptacji pacjentki oraz rodziny $w$ dążeniu do pożądanego efektu radzenia sobie ze chorobą.

2. Dorothy Orem (całkowicie kompensacyjny oraz wspierająco uczący) - ze względu na stan pacjentki wynikający z jednostki chorobowej oraz chorób współistniejących wymaga stałej kontroli masy ciała oraz podstawowych parametrów życiowych. 
Poniżej zaprezentowano najważniejsze problemy pielęgnacyjne opisywanej chorejw sposób tradycyjny oraz z wykorzystaniem ICNP(i).

Tabela 3.Proces pielęgnowania pacjentki z zespołem kacheksja anoreksja w opiece paliatywnej z wykorzystaniem ICNP ${ }^{\circledR}$.

\begin{tabular}{|c|c|}
\hline ny I & $\begin{array}{l}\text { Diagnoza negatywna (+kod } \\
\text { ICNP) }\end{array}$ \\
\hline Ból w obrębie jamy brzusznej & $\begin{array}{l}\text { Ból [10023130], Ból brzucha } \\
\text { [10043953]. }\end{array}$ \\
\hline $\begin{array}{l}\text { Cel planowanych działań } \\
\text { pielęgniarskich: }\end{array}$ & $\begin{array}{l}\text { Brak dolegliwości bólowych lub } \\
\text { odczuwanie bólu o słabym } \\
\text { natężeniu. }\end{array}$ \\
\hline $\begin{array}{l}\text { Planowane } \\
\text { pielęgniarskie: }\end{array}$ & $\begin{array}{l}\text { Interwencje pielęgniarskie } \\
\text { ICNP }{ }^{\circledR}:\end{array}$ \\
\hline 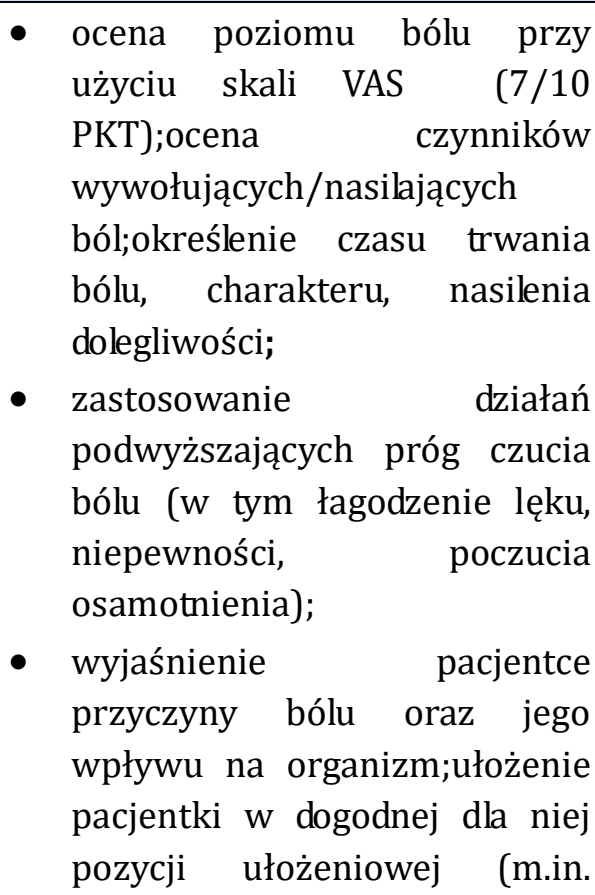 & 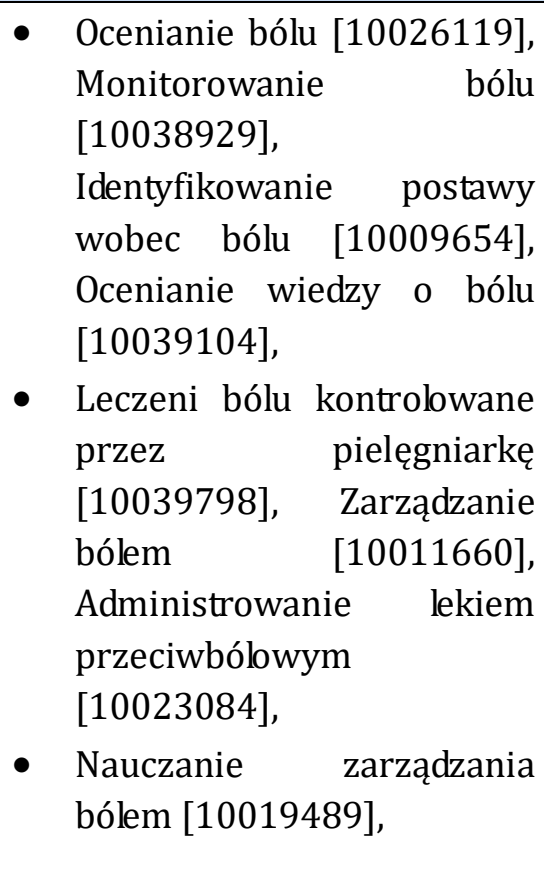 \\
\hline
\end{tabular}




\begin{tabular}{|c|c|}
\hline $\begin{array}{l}\text { Fowlera lub semi - Fowlera); } \\
\text { - udział w farmakologicznym } \\
\text { leczeniu bólu (zastosowanie } \\
\text { farmakoterapii zgodnie z IKZL); } \\
\text { zastosowanie } \\
\text { chłodzącego lub zimnego } \\
\text { okładu żelowego na okolicę } \\
\text { jamy brzusznej; } \\
\text { - } \begin{array}{l}\text { monitorowanie pod względem } \\
\text { reakcji na zastosowane } \\
\text { leczenie. nadu }\end{array}\end{array}$ & 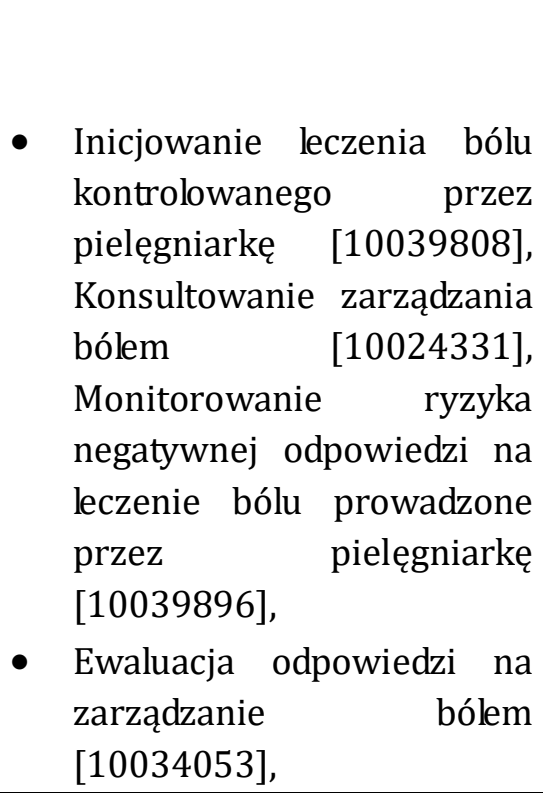 \\
\hline $\begin{array}{l}\text { Ocena realizowanych działań } \\
\text { pielęgniarskich: Dolegliwości } \\
\text { bólowe zmniejszyły się; kontrolna } \\
\text { ocena poziomu bólu przy użyciu } \\
\text { skali VAS( } 4 / 10 \text { pkt). }\end{array}$ & $\begin{array}{lr}\text { Diagniza } & \text { pozytywna } \\
\text { ICNP:Zredukowany } & \text { ból } \\
{[10027917]} & \end{array}$ \\
\hline \multicolumn{2}{|c|}{$\begin{array}{l}\text { Uzasadnienie planowanej interwencji pielęgniarskiej: W celu } \\
\text { efektywnej terapii przeciwbólowej należy regularnie dokonywać oceny } \\
\text { dolegliwości z uwzględnieniem natężenia, lokalizacji, czasu trwania } \\
\text { oraz charakteru bólu [1]. }\end{array}$} \\
\hline Problem pielęgnacyjny II & $\begin{array}{l}\text { Diagnoza negatywna (+kod } \\
\text { ICNP) }\end{array}$ \\
\hline $\begin{array}{l}\text { Trudność w komunikowaniu się } \\
\text { spowodowana afazją. }\end{array}$ & 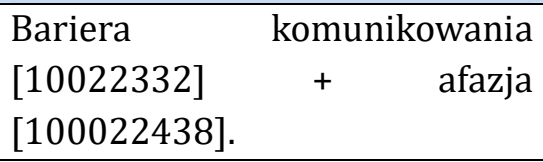 \\
\hline $\begin{array}{l}\text { Cel planowanych } \\
\text { pielęgniarskich: }\end{array}$ & Efektywna komunikacja \\
\hline
\end{tabular}




\begin{tabular}{|c|c|}
\hline $\begin{array}{l}\text { Planowane } \\
\text { pielęgniarskie: }\end{array}$ & $\begin{array}{l}\text { Interwencje pielęgniarskie } \\
\text { ICNP }{ }^{\circledR}:\end{array}$ \\
\hline $\begin{array}{l}\text { - } \text { nawiązanie kontaktu z } \\
\text { pacjentką, w celu zachęcenia jej } \\
\text { do mówienia; } \\
\text { uczenie chorej potakiwania lub } \\
\text { zaprzeczania (np. głową, ręką), } \\
\text { wymawiania słów tak lub nie } \\
\text { oraz wymawiania prostych } \\
\text { słów i zdań dotyczących potrzeb } \\
\text { oraz najbliższego otoczenia; } \\
\text { zapewnienie odpowiednich } \\
\text { warunków podczas komunikacji } \\
\text { z chorą; mówienie do pacjentki } \\
\text { cicho, powoli i wyraźnie oraz } \\
\text { krótkimi zdaniami; } \\
\text { okazywanie chorej } \\
\text { zrozumienia, życzliwości, } \\
\text { cierpliwości oraz chęci } \\
\text { pomocy;zwracanie uwagi z } \\
\text { uznaniem na uzyskane do tej } \\
\text { pory efekty terapeutyczne; } \\
\text { kształtowanie prawidłowej } \\
\text { postawy rodziny w opiece nad } \\
\text { pacjentką z afazją poprzez } \\
\text { realizację działań edukacyjnych } \\
\text { dotyczących przyczyny oraz } \\
\text { istoty choroby, reedukacji } \\
\text { mowy oraz nawiązywania } \\
\text { kontaktu; a }\end{array}$ & $\begin{array}{l}\text { - Nauczanie o ćwiczeniach } \\
{[10040125]+\text { efektywna }} \\
\text { zdolność komunikowania } \\
{[10014790],} \\
\text { Identyfikowanie przeszkody } \\
\text { w komunikacji [10009683], } \\
\text { - Wspieranier procesu } \\
\text { radzenia sobie rodziny } \\
{[10032859+\text { zaburzone }} \\
\text { funkcje poznawcze } \\
{[10012610] .}\end{array}$ \\
\hline Ocena & Diagniza \\
\hline
\end{tabular}




\begin{tabular}{|c|c|}
\hline $\begin{array}{l}\text { pielęgniarskich:Brak } r \text { zmiany } \\
\text { w zakresie komunikacji werbalnej; } \\
\text { nieznaczna poprawa w zakresie } \\
\text { wysyłania sygnałów przekazu } \\
\text { niewerbalnego. }\end{array}$ & $\begin{array}{l}\text { ICNP:Zaburzona komunikacja } \\
\text { werbalna [10025104] }\end{array}$ \\
\hline \multicolumn{2}{|c|}{$\begin{array}{l}\text { Uzasadnienie planowanej interwencji pielęgniarskiej: } \\
\text { Komunikacja niewerbalna stanowi zdecydowaną częśc przekazu } \\
\text { komunikatu i jest często, efektywnie wykorzystywana w praktyce } \\
\text { pielęgniarek w opiece paliatywnej }[8,9] \text {. }\end{array}$} \\
\hline Probl & $\begin{array}{l}\text { Diagnoza negatywna (+kod } \\
\text { ICNP) }\end{array}$ \\
\hline $\begin{array}{lrr}\text { Ryzyko wystąpienia } & \text { infekcji } \\
\text { z powodu } \quad \text { założonego } & \text { portu } \\
\text { donaczyniowego } & \end{array}$ & $\begin{array}{l}\text { Ryzyko infekcji }[10015133]+ \\
\text { podskórny port żylny } \\
{[10041436] \text {. }}\end{array}$ \\
\hline $\begin{array}{l}\text { Cel planowanych działań } \\
\text { pielęgniarskich: }\end{array}$ & $\begin{array}{l}\text { Brak infekcji. Zmniejszone } \\
\text { ryzyko infekcji. }\end{array}$ \\
\hline $\begin{array}{l}\text { Planowane } \\
\text { pielęgniarskie: }\end{array}$ & $\begin{array}{l}\text { Interwencje pielęgniarskie } \\
\text { ICNP }{ }^{\circledR} \text { : }\end{array}$ \\
\hline $\begin{array}{l}\text { - ocena ryzyka wystąpienia } \\
\text { powikłań w związku ze stałym, } \\
\text { długoterminowym dostępem } \\
\text { centralnym; ocena stanu } \\
\text { odżywienia i metabolizmu } \\
\text { organizmu; } \\
\text { - bezwzględne przestrzeganie } \\
\text { zasad aseptyki i antyseptyki na } \\
\text { każdym etapie obsługi portu } \\
\text { dożylnego; wykorzystywanie } \\
\text { do nakłuwania portu wyłącznie } \\
\text { igieł Hubera; } \\
\text { dobieranie odpowiedniej }\end{array}$ & 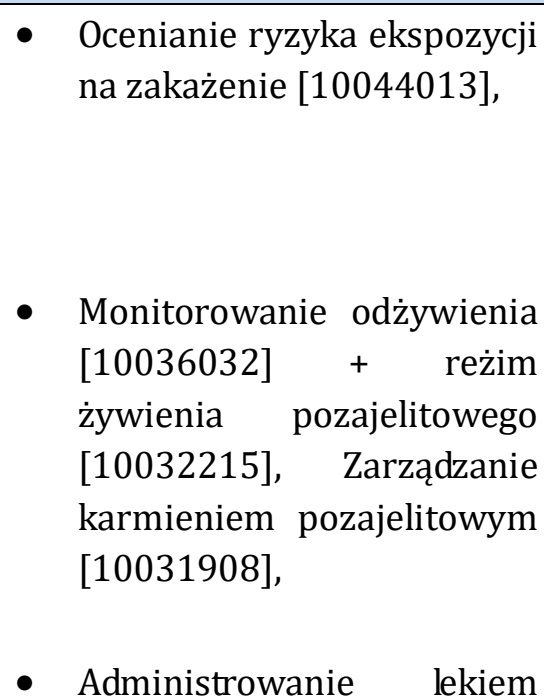 \\
\hline
\end{tabular}




\begin{tabular}{|c|c|}
\hline $\begin{array}{l}\text { grubości igieł (do żywienia } \\
\text { pozajelitowego grubości 18G- } \\
\text { 19G);wymiana igły co 24h (ze } \\
\text { względu na podawanie emulsji } \\
\text { tłuszczowych); } \\
\text { - płukanie portu bezpośrednio } \\
\text { po zakończeniu każdej iniekcji/ } \\
\text { infuzji (minimum } 20 \text { ml } 0,9 \% \\
\text { NaCl);zakładanie oraz usuwanie } \\
\text { igły zgodnie z procedurą; } \\
\text { prowadzenie codziennej } \\
\text { obserwacji miejsca wkłucia } \\
\text { i odnotowywanie tego faktu } \\
\text { w obowiązującej dokumentacji } \\
\text { medycznej;zabezpieczanie } \\
\text { portu przezroczystym, } \\
\text { okluzyjnym, jałowym } \\
\text { opatrunkiem (umożliwiającym } \\
\text { obserwację miejsca wkłucia } \\
\text { igły do portu). }\end{array}$ & $\begin{array}{l}\text { dożylnym [10045836], } \\
\begin{array}{l}\text { Implementacja } \\
\text { pozajelitowego [10046184], }\end{array} \\
\begin{array}{l}\text { Nauczanie rodziny o } \\
\text { chorobie [10021719] }\end{array} \\
\text { - } \begin{array}{l}\text { Pielęgnacja } \\
\text { wprowadzenia urządzeń }\end{array} \\
\begin{array}{l}\text { inwazyjnych [10031592] + } \\
\text { odpowiedź na żywienie } \\
\text { pozajelitowe [10017058], }\end{array}\end{array}$ \\
\hline $\begin{array}{l}\text { Ocena realizowanych działań } \\
\text { pielęgniarskich: Brak objawów } \\
\text { infekcji; drożność cewnika jest } \\
\text { zachowana. }\end{array}$ & \begin{tabular}{lcr}
\multicolumn{3}{l}{ Diagniza pozytywna ICNP:Bez } \\
infekcji & [10028945] & + \\
podskórny & port & żylny \\
{$[10041436]$.} & &
\end{tabular} \\
\hline $\begin{array}{l}\text { Uzasadnienie planowanej interwe } \\
\text { pozajelitowe jest potencjalnie } \\
\text { wspomagającym żywienie u pacjen } \\
\text { alternatywna dojelitowa. Żywieni } \\
\text { ostrożnie inicjowane oraz monitor }\end{array}$ & $\begin{array}{l}\text { cji pielęgniarskiej: Żywienie } \\
\text { catującym życie środkiem } \\
\text { w, u których niemożliwa jest } \\
\text { pozajelitowe powinno być } \\
\text { ane przez multidyscyplinarny }\end{array}$ \\
\hline
\end{tabular}




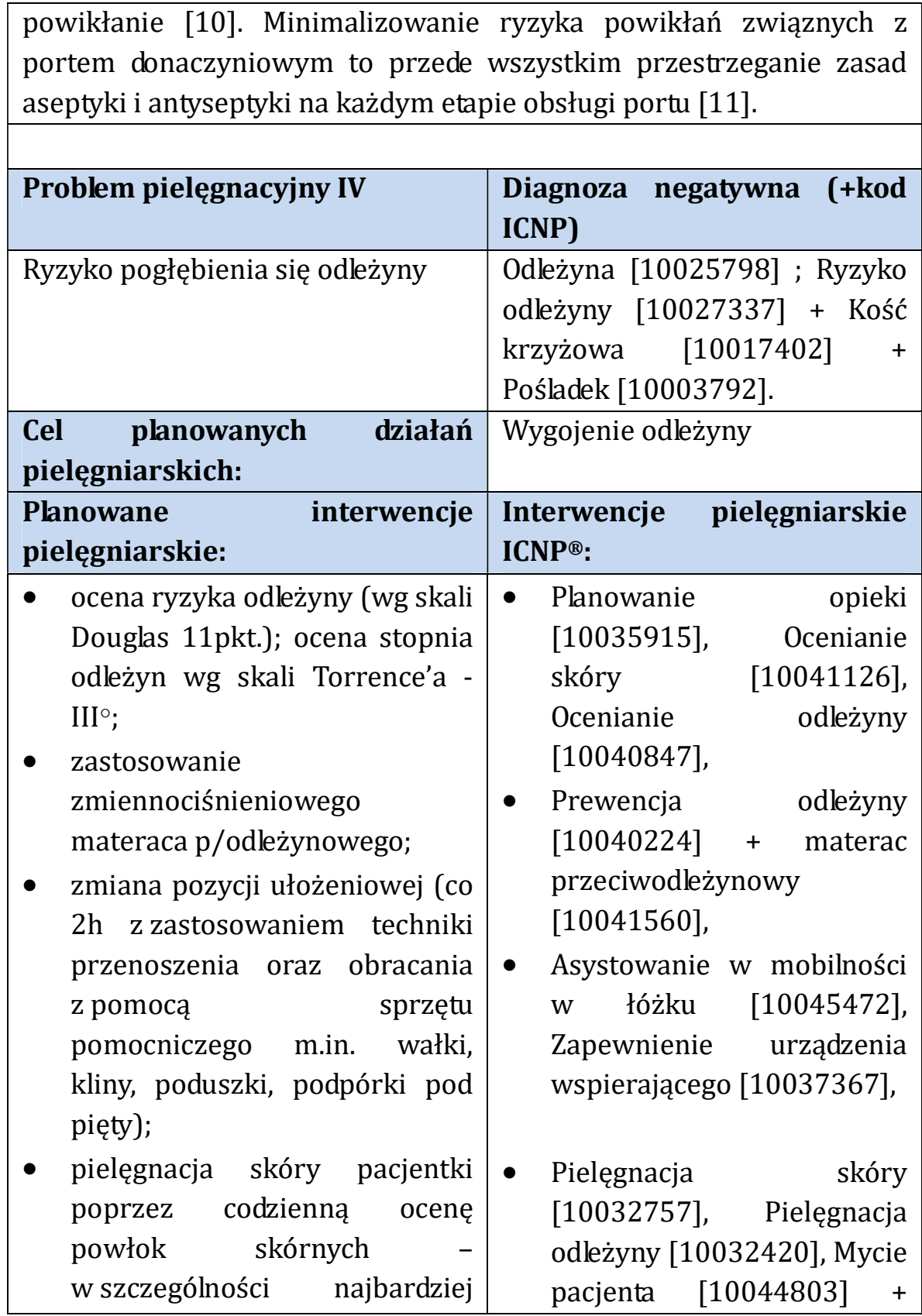




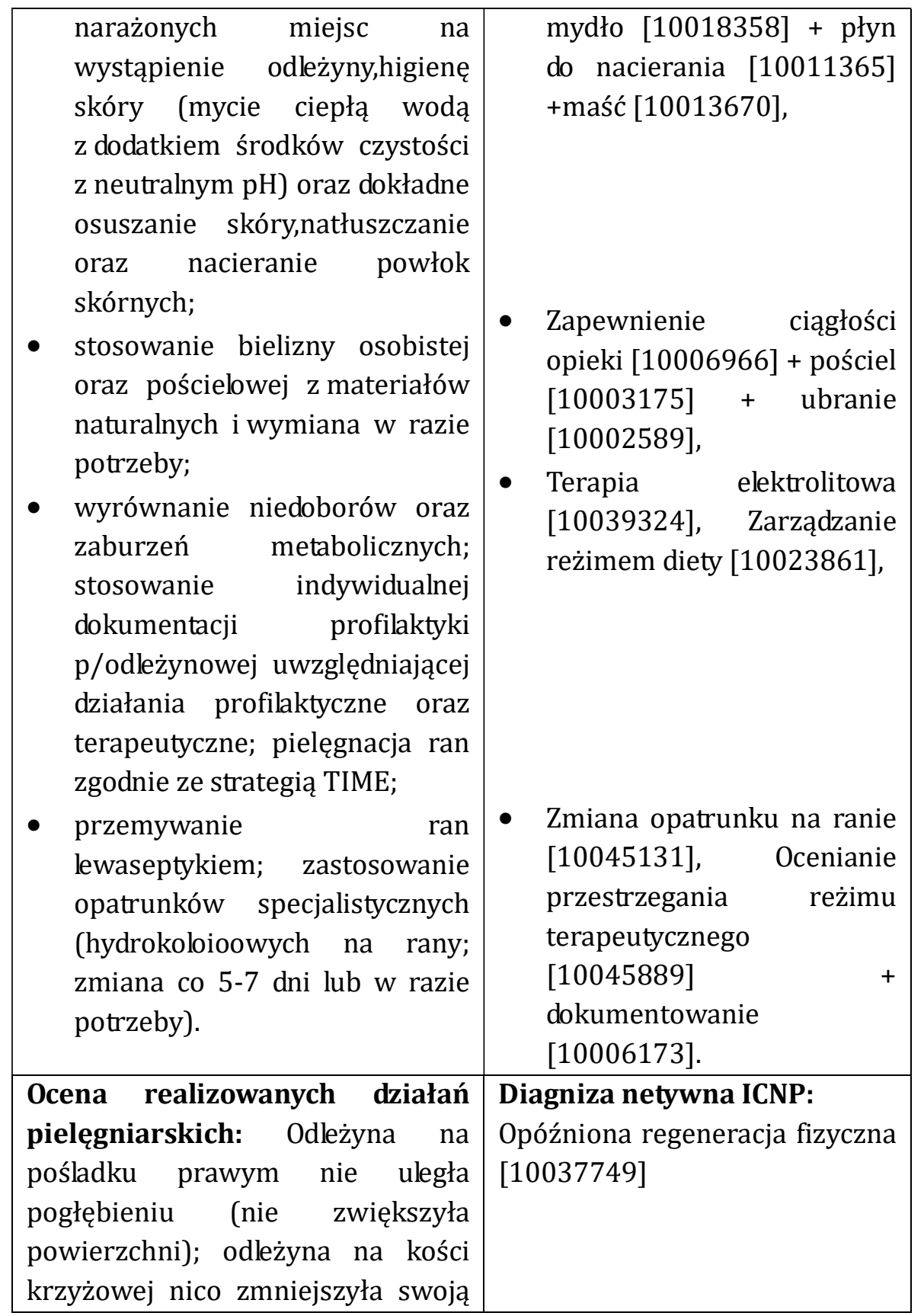




\begin{tabular}{|c|c|}
\hline $\begin{array}{l}\text { wielkość (obecnie } 2,5 \mathrm{~cm} \times 2 \mathrm{~cm} \text { ) } \\
\text { Ryzyko pogłębienia się odleżyny } \\
\text { utrzymuje się. }\end{array}$ & \\
\hline Uzasadnienie $\quad$ planowanej & interwencji pielęgniarskiej: \\
\hline $\begin{array}{l}\text { Zapobieganie odleżynom należy wła } \\
\text { samego początku hospitalizacji. Oce } \\
\text { oraz pielęgnacja skóry powinna b } \\
\text { odleżynom oraz pogłębiania ich [12] }\end{array}$ & $\begin{array}{l}\text { ączyć do opieki nad pacjentem od } \\
\text { eny ryzyka na poziomie oddziału } \\
\text { yć odpowiednia do zapobiegania } \\
\text { ]. }\end{array}$ \\
\hline
\end{tabular}

\section{Dyskusja}

Rak jest drugą co do częstości przyczyną zgonów na świecie. Według raportu Global Burden of Disease Cancer Collaboration (Globalnej Współpracy w Zwalczaniu Choroby Nowotworowej), w roku 2015 zdiagnozowano 17,5 mln. przypadków raka, natomiast zgonów w wyniku tej choroby były 8,7 mln. $[13,14]$. W chorobie nowotworowej obok objawów spowodowanych rozrostem nowotorowym w określonym narządzie lub tkance, występują także liczne objawy ogólne, takie jak zmęczenie, ból oraz jadłowstręt [14]. Objawy te mogą wtórnie prowadzić do kacheksji, która jest jednym z najczęstszych zespołów metabolicznych u pacjentów z zaawansowaną chorobą nowotworową [3]. Kacheksji towarzyszy zmniejszenie aktywności i wydolności fizycznej, co powoduje wzrost względnego odczucia ciężkości wysiłku fizycznego. Wpływa to na pogorszenie jakości życia, co jest zauważalne u opisywanej pacjentki. Obniżony nastrój wynikał nie tylko z lęku o przyszłość, ale także $\mathrm{z}$ braku samodzielności oraz ograniczenia $\mathrm{w}$ obszarze komunikowania się z innymi.

Jednym z najbardziej uciążliwych objawów u opisywanej chorej był ból. Dolegliwość ta jest jednym z najczęstszych objawów diagnozowanych u pacjentów w opiece paliatywnej. Z uwagi na jego charakter oraz wielowymiarowość, ból u chorych na nowotwór jest 
często bólem wszechogarniającym [1]. W praktyce pielęgniarskiej bardzo ważna jest wnikliwa obserwacja czynników wywołujących ból. Ponadto należy regularnie dokonywać oceny dolegliwości z uwzględnieniem natężenia, lokalizacji, czasu trwania oraz charakteru bólu [1]. Stałe monitorowanie bólu oraz wdrażanie leczenia przeciwbólowego zgodnie $\mathrm{z}$ zasadami trójstopniowej drabiny analgetycznej opracowanej przez WHO (World Health Organization Światowa Organizacja Zdrowia) oraz podjęte działania niefarmakologiczne pozwoliły zmniejszyć natężenie odczuwanego bólu podczas realizacji zaplanowanej opieki pielęgniarskiej.

Opanowanie umiejętności komunikacji stanowi podstawę dobrej współpracy między zespołem interdyscyplinarnym, a pacjentem w stanie terminalnym i jego rodziną [15]. Szczególnie w sytuacji, kiedy chory ma zaburzone możliwości wyrażania swoich potrzeb, ważne jest profesjonalne, oparte na wiedzy i doświadczeniu oraz wspierające podejście do problemu. W opiece paliatywnej szczególnego znaczenia nabiera forma komunikacji niewrbalnej. Szacuje sie, że zdecydowana większość komunikatu jest przekazywana w takiej formie [8]. W badaniu Kozłowskiej i Doboszyńskiej wykazano, że 48\% pielęgniarek pracujących w opiece paliatywnej często, celowo wykorzystuje niewerbalne środki przekazu wswojej codziennej praktyce zawodowej. Najczęściej stosowane są wówczas dotyk, wyraz twarzy oraz kontakt wzrokowy [9]. Należy także pamietać, że zarówno komunikacja, jak i inne umiejętności interpersonalne mają istotny wpływ na jakość opieki pielęgniarskiej [11].

W realizacji opieki nad opisywaną chorą, dużo uwagi zostało zwrócone na naukę świadomego wykorzystywania niewerbalnych środków przekazu w codziennej komunikacji. Niestety okazało się, że dwutygodniowy okres realizacji opieki był niewystarczający, aby uzyskaćoczekiwane, pozytywne efekty podjętych działań oraz zwiększyć efektywność komunikacji między chorą, a zespołem interdyscyplinarnym oraz najbliższymi. Zauważono jedynie niewielką poprawę w tym obszarze. 
Według Argiles i współ., główne zmiany metaboliczne związane z rozwojem zespołu kacheksja-anoreksja to nietolerancja glukozy, niedobór tłuszczy i hiperkatabolizm białek mięśniowych. Podejście wielopłaszczyznowe wydaje się niezbędne w terapiach, które powinny obejmować połączenie zarówno wsparcia żywieniowego, leków, jak i odpowiedniego programu ćwiczeń fizycznych, w celu złagodzenia zarówno anoreksji, jak i zmian metabolicznych związanych z kacheksją [16]. Żywienie pozajelitowe jest potencjalnie ratującym życie środkiem wspomagającym żywienie u pacjentów, u których niemożliwa jest droga dojelitowa [10]. W opisywanym przypadku stosowano żywienie pozajelitowe przy użyciu portu donaczyniowego, co pozwoliło na dostarczanie optymalnej ilości poszczególnych składników odżywczych. Niemniej w trakcie realizacji świadczeń pielęgnacyjnych, takich jak karmienie drogą pozajelitową, należy pamiętać o zasadach obowiązujących podczas obsługi portu donaczyniowego, których głównym celem jest uniknięcie infekcji oraz zapewnienie drożności cewnika. Chcąc zapewnić chorej bezpieczeństwo oraz najwyższą jakość realizowanych świadczeń, obsługa portu była realizowana zgodnie z Procedurą obsługi zaimplantowanego portu dożylnego rekomendowaną przez Polskie Stowarzyszenie Pielęgniarek Onkologicznych [7].

Zmiany skórne występujące u pacjentów w opiece paliatywnej znacznie utrudniają właściwą kontrolę pozostałych objawów, a przez to wpływają istotnie na pogorszenie jakości życia chorych [1]. Szacuje się, że odleżyny występują u co najmniej $1 / 3$ chorych w opiece paliatywnej [17]. Zapobieganie odleżynom należy włączyć do opieki nad pacjentem od samego początku hospitalizacji [12]. Ważne w codziennej pielęgnacji są działania profilaktyczne oraz uważna obserwacja skóry chorego. Analizowany przypadek chorej, wymagał nie tylko podjęcia działań profilaktycznech, ale także zaopatrzenia oraz pielęgnacji istniejących już ran. Należy pamiętać, że jedną z najważniejszych zasad pielęgnacji odleżyn jest utrzymanie wilgotnego środowiska rany. Ułatwia to proces gojenia oraz zmniejsza 
dolegliwości bólowe, które często występują wśród chorych objętych opieką paliatywną [17]. Zgodnie z aktualnymi zaleceniami Polskiego Towarzystwa Leczenia Ran, pielęgnacja ran była realizowana w oparciu o algorytm TIME [1]. Dodatkowo wdrożenie działań profilaktycznych oraz pielęgnacja ran przy użyciu lewaseptyku i opatrunku specjalistycznego (hydrokoloid) pozwoliły na zahamowanie rozwoju rany, a także niewielkie zmniejszenie zmienionego obszaru w okolicy kości krzyżowej.

Wdrożenie działań zapobiegających rowojowi problemów pielęgnacyjnych pacjentki stanowi wyzwanie dla zespołu terapeutycznego oraz rodziny. Zaproponowany plan opieki pielęgniarskiej miał przede wszystkim, zgodnie $\mathrm{w}$ priorytetem realizowanej opieki, podnieść jakość życia chorej. Dokonanie mapowania interwencji $\mathrm{z}$ wersji tradycyjnego planu opieki pielęgniarskiej zgodnie ze standardami Międzynarodowej Rady Pielęgniarek na wersje ICNP $^{\circledR}$ prowadziło do poprawy jakości wykonywanych świadczeń w zakresie pielęgnacji pacjentki w opiece paliatywnej.

\section{Wnioski}

Zaburzenia metaboliczne, dolegliwości bólowe, trudności w komunikowaniu się oraz liczne inne problemy zdiagnozowane u pacjentki stanowiły wyzwanie dla pielęgniarki w zakresie ich oceny oraz ustalaniu hierarchii podczas formułowania planu opieki. Odpowiednio szybkie diagnozowanie problemów oraz podejmowanie efektywnych interwencji przełożyło się jednak na poprawę funkcjonowania chorej. Ważnym aspektem prowadzonej terapii było także skuteczne wsparcie żywieniowe.

Holistyczny model opieki polega na systematycznej ocenie 
ogólnego stanu zdrowia oraz monitorowaniu efektywności pojmowanych działań, a nieodłącznym jego elementem jest również ocena jakości życia. Wśród zadań realizowanych przez pielęgniarkę należy uwzględniać również edukowanie najbliższych chorej, co zwiększa ich świadomość czynnego udziału w procesie terapeutycznym.

Zastosowanie Międzynarodowej Klasyfikacji Praktyki Pielęgniarskiej ICNP $^{\circledR}$ w planowaniu opieki pielęgniarskiej nad pacjentką $\mathrm{z}$ zespołem kacheksja - anoreksja umożliwiło monitorowanie oraz poprawę efektywności oraz jakości udzielanych świadczeń w procesie terapeutycznym.

\section{Bibliografia/Biblography:}

1.Kaptacz A., Walden- Gałuszko K. Pielęgniarstwo opieki paliatywnej. Wydawnictwo Lekarskie PZWL. Warszawa 2016.

2.Bączyk M., Gorzelińska L., Łuczak J., Sowiński J,: Zespół wyniszczenia nowotworowego. Wpływ leczenia na wybrane parametry kliniczne i biochemiczne. Doniesienie wstępne. Polska Medycyna Paliatywna 2005, 4, 1, $11-16$.

3.Hui D. Cancer Cachexia. It Takes a Team to Fix the Complex Machinery. Clinical Review 2016; 12 (11): 1172-1174.

4.Buduhan V., Cashman R., Cooper E. Symptom Management Guidelines: ANOREXIA and CACHEXIA. BC Cancer Agency 2014.

5.Grabiec, K., Burchert, M., Milewska i wsp. Ogólnoustrojowe i miejscowe mechanizmy prowadzące do kacheksji w chorobach nowotworowych. Postępy Higieny i Medycyny Doświadczalnej 2013, 67: 1397-1409.

6.Modlińska A., Wyszadko A. Zespół wyniszczenia w przebiegu choroby nowotworowej z uwzględnieniem leczenia octanem megestrolu. Medycyna Paliatywna. 2012; 2: 67-74. 
7.Jobda B., Pasek M (red.). Procedura obsługi zaimplementowanego portu dożylnego. Polskie Stowarzyszenie Pielęgniarek Onkologicznych. Warszawa 2015.

8.Pease A. Mowa ciała. Jak odczytać myśli innych ludzi z ich gestów. Jedność, Kielce 2001:10.

9.Kozłowska L., Doboszyńska A. Nurses' nonverbal methods of communicating with patients in the terminal phase. International Journal of palliativeNursing. 2012; Vol 18, No1: 40-46.

10.Ghosh D., Neild P.,: Parenteral nutrition. ClinMed (Lond). 2010 Dec; 10(6): 620-623.

11.Lesińska-Sawicka M (red.). Metoda Case Study w pielęgniarstwie. Borgis Wydawnictwo Medyczne 2009.

12.MuntlinAthlin Å.,EngströmM.,Gunningberg L.,Bååth C., Heel pressure ulcer, prevention and predictors during the care delivery chain - when and where to take action? A descriptive and explorative study. Scand J Trauma ResuscEmergMed 2016; 24: 134.

13.Fitzmaurice C., Allen C., Barber RM., et al Global, regional, and National Cancer Incidence, mortality, years of life lost, years lived with disability, and disability-adjusted life-years for 32 Cancer groups, 1990 to 2015. JAMA Oncol. 2017;3(4):524-548.

14.Zhang F., Shen A.Jin Y.,Qiang W.The management strategies of cancerassociated anorexia: a critical appraisal of systematic reviews. BMC Complement Altern Med. 2018; 18: 236.

15.Kleja J., Filipczak-Bryniarska I., Wordliczek J. Komunikacja w opiece paliatywnej. Medycyna Paliatywna w Praktyce 2010; 4, 2, 81-85.

16.Argilés JM., Busquets S., López-Soriano FJ. Cancer cachexia, a clinical challenge. Curr Opin Oncol 2019 Mar 18.

17.Kepma S., Klich D., Zaporowska-Stachowiak I., Soptara M. Odleżyny 
u pacjentów w terminalnej fazie choroby. Leczenie Ran. 2016;13(4):147-155.

Otrzymano: 13.03.2019r.

Zaakceptowano: 21.04.2019r. 